\title{
Bat Influenza A(HL18NL11) Virus in Fruit Bats, Brazil
}

\author{
Angélica Cristine Almeida Campos, \\ Luiz Gustavo Bentim Góes, Andres Moreira-Soto, \\ Cristiano de Carvalho, Guilherme Ambar, \\ Anna-Lena Sander, Carlo Fischer, \\ Adriana Ruckert da Rosa, \\ Debora Cardoso de Oliveira, \\ Ana Paula G. Kataoka, Wagner André Pedro, \\ Luzia Fátima A. Martorelli, \\ Luzia Helena Queiroz, Ariovaldo P. Cruz-Neto, \\ Edison Luiz Durigon, ${ }^{1}$ Jan Felix Drexler ${ }^{1}$
}

Screening of 533 bats for influenza A viruses showed subtype HL18NL11 in intestines of 2 great fruit-eating bats (Artibeus lituratus). High concentrations suggested fecal shedding. Genomic characterizations revealed conservation of viral genes across different host species, countries, and sampling years, suggesting a conserved cellular receptor and wide-ranging occurrence of bat influenza $A$ viruses.

I nfluenza A viruses are major causes of human disease and are predominantly maintained in avian reservoirs ( $(1)$. The segmented influenza A genome facilitates reassortment events in birds or intermediate hosts, such as swine and horses, leading to emergence of new variants potentially capable of causing zoonotic infections (2). Bats are major sources of zoonotic pathogens (3). In pioneering studies from 2012 and 2013, the first bat influenza A viruses,

Author affiliations: Charité-Universitätsmedizin Berlin, corporate member of Freie Universität Berlin, Humboldt-Universität zu Berlin, and Berlin Institute of Health, Institute of Virology, Berlin, Germany (A.C.A. Campos, L.G.B. Góes, A. Moreira-Soto, A.-L. Sander, C. Fischer, J.F. Drexler); Universidade de São Paulo-USP, Instituto de Ciências Biomédicas-ICB, São Paulo, Brazil (A.C.A. Campos, L.G.B. Góes, E.L. Durigon); Universidade Estadual Paulista Faculdade de Medicina Veterinária de Araçatuba, Araçatuba, Brazil (C. de Carvalho, W.A. Pedro, L.H. Queiroz); Universidade Estadual Paulista, Instituto de Biociências, Rio Claro, Brazil (G. Ambar, A.P. Cruz-Neto); Centro de Controle de Zoonoses, São Paulo (A.R. da Rosa, D.C. de Oliveira, L.F.A. Martorelli, A.P.G. Kataoka); German Centre for Infection Research, Germany (J.F. Drexler); Martsinovsky Institute of Medical Parasitology, Tropical and Vector-Borne Diseases, Sechenov University, Moscow, Russia (J.F. Drexler) termed H17N10 and H18N11, were discovered in 2 bat species, Sturnira lilium (little yellow-shouldered bat) and Artibeus planirostris (flat-faced fruit-eating bat) $(4,5)$.

Bat-associated influenza A viruses are phylogenetically highly divergent from avian-associated influenza A viruses in their hemagglutinin (HA) and neuraminidase (NA) genes, suggesting these viruses represent ancient influenza A strains (2). Consistent with their genetic divergence, batassociated influenza A surface proteins lack typical hemagglutination and neuraminidase activities (6), leading to the terminology HA-like (HL) and neuraminidase-like (NL) for bat-associated influenza surface proteins.

So far, only 4 individual bat specimens yielded influenza A genomic sequences during the pivotal investigations $(4,5)$. HL18NL11 has only been found in 1 A. planirostris bat captured in Peru in 2010 (5), challenging definite host assessments. To investigate bat influenza A virus epidemiology, we investigated bats in southern Brazil during 2010-2014.

\section{The Study}

For this study, we sampled 533 individual bats representing 26 species and 3 families across 28 sampling sites (Table 1). Bats were captured using mist nets, euthanized, and necropsied and were identified on the basis of morphological criteria by trained field biologists as described previously (7). Only intestine samples were available for virological analyses. The Instituto Brasileiro do Meio Ambiente e dos Recursos Naturais (21748-1), Instituto Ambiental do Paraná (235/10), and the ethics committee of the Institute of Biomedical Science from the University of São Paulo (56-18-03/2014) authorized sampling.

We tested intestine specimens from all bats using 2 highly sensitive, broadly reactive nested reverse transcription PCRs targeting different regions of the influenza A polymerase basic (PB) 1 gene $(5,8)$. Positive results on both tests came from only 2 samples, from Artibeus lituratus great fruit-eating bats captured on March 7 and March 12, 2012, at 2 locations separated by $12 \mathrm{~km}$ in an Atlantic rainforest patch. No other sample was positive, yielding a $10.0 \%(2 / 20)$ overall detection rate in this site and $16.7 \%(2 / 12)$ detection in A. lituratus bats from this site (Table 1; Figure 1, panel A). Neither bat testing positive for influenza A virus showed signs of disease. 
Table 1. Bat species screened for influenza A virus, Brazil, 2010-2014*

\begin{tabular}{|c|c|c|c|c|c|}
\hline Species & Family & $\begin{array}{c}\text { No. } \\
\text { samples }\end{array}$ & $\begin{array}{l}\text { No. (\%) PCR } \\
\text { positive }\end{array}$ & Sampling site & Sampling years \\
\hline Artibeus fimbriatus & Phyllostomidae & 3 & 0 & Iguaçu & 2012 \\
\hline Artibeus lituratus & Phyllostomidae & 129 & $2(1.6)$ & $\begin{array}{c}\text { Iguaçu, Central Paraná state, } \\
\text { São Paulo cities }\end{array}$ & $\begin{array}{c}2010,2011,2012 \\
2013,2014\end{array}$ \\
\hline Artibeus obscurus & Phyllostomidae & 1 & 0 & São Paulo cities & 2013 \\
\hline Artibeus planirostris & Phyllostomidae & 4 & 0 & $\begin{array}{c}\text { Iguaçu, Central Paraná state, } \\
\text { São Paulo cities }\end{array}$ & $2010,2012,2014$ \\
\hline Carollia perspicillata & Phyllostomidae & 44 & 0 & Iguaçu, Central Paraná state & 2010-2012 \\
\hline Cynomops planirostris & Molossidae & 6 & 0 & São Paulo cities & 2014 \\
\hline Desmodus rotundus & Phyllostomidae & 15 & 0 & São Paulo cities & 2014 \\
\hline Eptesicus furinalis & Vespertilionidae & 8 & 0 & São Paulo cities & 2013-2015 \\
\hline Eumops auripendulus & Molossidae & 1 & 0 & São Paulo cities & 2014 \\
\hline Eumops glaucinus & Molossidae & 44 & 0 & São Paulo cities & 2013-2015 \\
\hline Eumops perotis & Molossidae & 8 & 0 & São Paulo cities & 2014-2015 \\
\hline Glossophaga soricina & Phyllostomidae & 27 & 0 & São Paulo cities & 2013-2015 \\
\hline Lasiurus cinereus & Vespertilionidae & 1 & 0 & São Paulo cities & 2013 \\
\hline Lasiurus ega & Vespertilionidae & 1 & 0 & São Paulo cities & 2014 \\
\hline Molossus molossus & Molossidae & 115 & 0 & São Paulo cities & 2013-2015 \\
\hline Molossus rufus & Molossidae & 63 & 0 & São Paulo cities & 2013-2015 \\
\hline Myotis nigricans & Vespertilionidae & 13 & 0 & São Paulo cities & 2013-2015 \\
\hline Myotis riparius & Vespertilionidae & 1 & 0 & São Paulo cities & 2013 \\
\hline Nyctinomops laticaudatus & Molossidae & 3 & 0 & São Paulo cities & 2014-2015 \\
\hline Nyctinomops macrotis & Molossidae & 1 & 0 & São Paulo cities & 2014 \\
\hline Phyllostomus discolor & Phyllostomidae & 2 & 0 & São Paulo cities & 2014 \\
\hline Platyrrhinus lineatus & Phyllostomidae & 4 & 0 & São Paulo cities & 2014 \\
\hline Promops nasutus & Molossidae & 1 & 0 & São Paulo cities & 2014 \\
\hline Sturnira lilium & Phyllostomidae & 28 & 0 & Iguaçu, Central Paraná state & 2010-2012 \\
\hline Tadarida brasiliensis & Molossidae & 9 & 0 & São Paulo cities & 2014 \\
\hline Vampyressa pusila & Phyllostomidae & 1 & 0 & Central Paraná state & 2012 \\
\hline Total & & 533 & $2(0.4)$ & & \\
\hline
\end{tabular}

A. lituratus bats were the most abundantly sampled species (Table 1).

The low overall influenza virus detection rate in this study $(0.4 \%, 95 \%$ CI $0.0 \%-1.5 \%)$ was not significantly different by Fisher exact test from the previous 2 studies (1/110 bats for HL18NL11 [0.9\%, 95\% CI 0.0\%-5.5\%; p $=0.43] ; 3 / 316$ bats for HL17NL10 [1.0\%, 95\% CI $0.0 \%-$ $2.9 \% ; \mathrm{p}=0.37])$. Apparently low rates of acute influenza A virus infection in bats are not consistent with high seroprevalence of $72 \%$ in different bat species according to a preliminary investigation (5) and may hint at seasonal variation in bat influenza virus infections, comparable to other batborne RNA viruses (9).

Sanger sequencing of the screening PCR amplicons suggested close genetic relatedness of the strains circulating in Brazil with the HL18NL11 strain circulating in Peru. Virus concentrations in the positive intestine specimens as determined by strain-specific quantitative real-time reverse transcription RT-PCR (Appendix Table 1, https://wwwnc. cdc.gov/EID/article/25/2/18-1246-App.pdf) were high $\left(1.5 \times 10^{9}\right.$ and $4.9 \times 10^{10}$ RNA copies/g of tissue $)$. High HL18NL11 concentrations in intestinal specimens are consistent with qualitative data from the pioneering study on HL18NL11 (5) and may suggest intestinal tropism and potential fecal shedding into the environment.
We determined the full coding sequence of all 8 segments of the viral genomes using primers aiming at amplifying overlapping regions of bat influenza A virus genomes (GenBank accession nos. MH682200-15) (Appendix Table 1). The 2 HL18NL11 variants in Brazil differed by $15 \mathrm{nt}$ from each other across the combined 8 genomic segments. Four of those substitutions were nonsynonymous, causing amino acid exchanges in the PB2 (V203I), PB1 (R334K), nucleoprotein (G484S), and NA (V191I) genes (Table 2; Figure 1, panel B). This finding suggests recent common ancestry of the HL18NL11 variants identified in the 2 positive bats and was consistent with their detection in the same site 5 days apart. Comparison of the full coding sequence of the novel HL18NL11 variants revealed high sequence identity between the Peru and the Brazil strains, $93.5 \%-96.9 \%$ nucleotide identity across all 8 genomic segments (Table 2). The genomic relatedness of Peru and Brazil HL18NL11 strains was surprising given a time span of 2 years, a geographic distance exceeding 2,000 km, and 2 different bat species that tested positive in our study and the previous study (5).

All critical amino acid residues associated with influenza A virus replication and entry $(4,5)$ were conserved between the Brazil and the Peru HL18NL11 strains, including the HA monobasic cleavage site motif 
Figure 1. Bat influenza $\mathrm{A}(\mathrm{HL} 18 \mathrm{NL} 11)$ virus detection and genomic characterization, Brazil, 2010-2014. A) Distribution of Artibeus species bats carrying HL18NL11 in Central and South America, according to the Red List of Threatened Species from the International Union for Conservation of Nature (https:// www.iucnredlist.org). Orange star indicates the sampling site of an HL18NL11-positive bat in Peru (5); blue star indicates the sampling site of the HL18NL11positive bats in Brazil for this study. Maps were created using QGIS2.14.3 (http://www.qgis.org) with data freely available from http://www.naturalearthdata.com. B) Top, schematic representation of the genome organization of $A / g r e a t$ fruit-eating bat/ Brazil/2301/2012 (HL18NL11) and amino acid exchanges (black lines) compared with A/great fruit-eating bat/Brazil/2344/2012 (HL18NL11) and Peru HL18NL11 (GenBank accession nos. CY125942-49). Nucleotide sequence identities between the concatenated HL18NL11 (Brazil), HL17NL10, and HL18NL11 (Guatemala and Peru) sequences were calculated in SSE version 1.2 (http://www.virus-evolution.org/Downloads/Software) with a sliding window of 200 and step size of $100 \mathrm{nt}$. C) Homology model of the $\mathrm{HL}$ protein of A/great fruit-eating bat/Brazil/2301/2012 viewed from the top, modeled on the published crystal structure retrieved from the SWISS-MODEL repository (https://www.swissmodel.expasy.org). The putative RBS is shown in blue, 3 highly conserved residues (W153, H183, and Y195) in HAs and HLs are in purple, and amino acid substitutions between Brazil strains and the Peru prototype strain are in red. D) Homology model of the NL of A/great fruit-eating bat/Brazil/2301/2012 viewed from the top, constructed as in panel $C$. The putative active site is shown in a blue circle, the 6 residues (R118, W178, S179, R224, E276 and E425) conserved in influenza A virus neuraminidase genes are in purple, and amino acid substitutions between Brazil strains and the Peru prototype strain are in red. HA, hemagglutinin; HL, hemagglutinin-like; NL, neuraminidase-like; RBS, receptor-binding site.
PIKETR/GLF (5). Thermodynamic modeling revealed that the amino acid exchanges observed between the Brazil and Peru HL18NL11 strains did not alter the tridimensional structure of the HL and NL proteins, and neither mapped to the putative receptor binding site of the HL protein (Figure 1, panel C), nor to the putative active site of the NL protein (Figure 1, panel D) (6). This result suggests preservation of the biologic activity of these glycoproteins in different bat species and supported a broadly conserved cellular receptor of bat influenza A viruses that differs from sialic acid receptors used by avian-associated influenza A viruses (10). Significantly fewer amino acid exchanges were observed between the HL proteins of Brazil and Peru bat influenza virus than between the respective NL proteins ( $p$ $=0.007$ by Fisher exact test) (Table 2 ). The apparently

\begin{tabular}{|c|c|c|c|}
\hline & & \multicolumn{2}{|c|}{ Amino acid exchange site } \\
\hline Gene & $\begin{array}{l}\text { Nucleotide sequence } \\
\text { identity }\end{array}$ & $\begin{array}{c}\text { A/great fruit-eating bat/Brazil/2301/2012 } \\
\text { (HL18NL11a) }\end{array}$ & $\begin{array}{c}\text { A/great fruit-eating bat/Brazil/2344/2012 } \\
\text { (HL18NL11b) }\end{array}$ \\
\hline PB2 & $93.6 \%$ & $\begin{array}{c}\text { V76I, R471K, T473N, V478I, I559V, R574K, } \\
\text { S631N }\end{array}$ & $\begin{array}{c}\text { V76I, V203I, R471K, T473N, V478I, I559V, } \\
\text { R574K, S631N }\end{array}$ \\
\hline PB1 & $93.7 \%$ & V54I, T56V & V54I, T56V, R334K \\
\hline PA & $94.4 \%$ & $\begin{array}{l}\text { T70A, R116K, D158N, V231I, T254S, I552V, } \\
\text { R711G }\end{array}$ & $\begin{array}{l}\text { T70A, R116K, D158N, V231I, T254S, I552V, } \\
\text { R711G }\end{array}$ \\
\hline $\mathrm{HL}$ & $96.0 \%$ & N167T, F251L & N167T, F251L \\
\hline NP & $96.8 \%-96.9 \%$ & N20T, K350R, L357M, I380L, I387V & N20T, K350R, L357M, I380L, I387V, G484S \\
\hline $\mathrm{NL}$ & $93.5 \%$ & $\begin{array}{l}\text { I11V, I15L, V82I, V200I, L254I, A264T, V284I, } \\
\text { D332E, V378I, G382E }\end{array}$ & $\begin{array}{l}\text { I11V, I15L, V82I, V191I, V200I, L254I, A264T, } \\
\text { V284I, D332E, V378I, G382E }\end{array}$ \\
\hline M & $95.4 \%$ & None & None \\
\hline NS1 & $94.4 \%$ & R57K & R57K \\
\hline
\end{tabular}

*Bold indicates amino acid exchanges occurring in only 1 of the 2 Brazil strains compared to the Peru prototype strain. HA, hemagglutinin; HL, HA-like; M, matrix; NA, neuraminidase; NL, neuraminidase-like; NS, nonstructural protein; NP, nucleoprotein; PA, polymerase acidic; $\mathrm{PB}$, polymerase basic. 

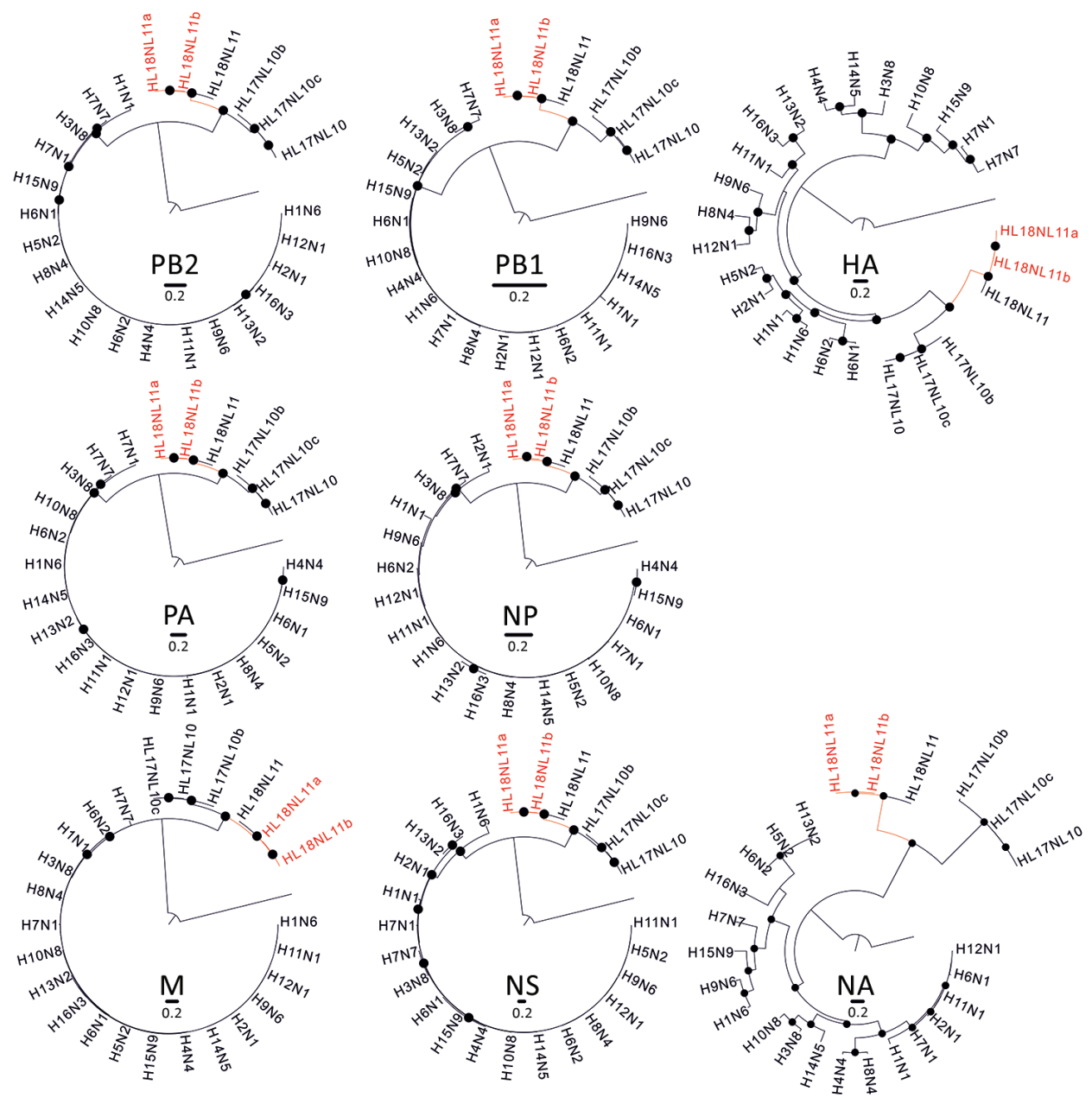

Figure 2. Phylogenetic relationships between bat influenza A viruses from Brazil and reference viruses. Phylogenetic trees show comparison of the 8 segments of representative influenza $A$ virus genomes (PB2, PB1, PA, HA/HL, NP, NA/ $\mathrm{NL}, \mathrm{M}, \mathrm{NS}$ ) with $\mathrm{A} / \mathrm{great}$ fruiteating bat/Brazil/2301/2012 (HL18NL11a; GenBank accession nos. MH682200-7) and $\mathrm{A} / \mathrm{great}$ fruit-eating bat/ Brazil/2344/2012 (HL18NL11b; GenBank accession nos. MH682208-15), shown in red. Maximum-likelihood trees were inferred using a general timereversible substitution model with a gamma distribution and invariant sites. Black dots represent bootstrap values $\geq 75 \%$ (1,000 replicants). Trees were generally rooted using influenza B/Lee/1940 (GenBank accession nos. DQ792894-901) (data not shown). Trees were constructed by using MEGA 6.0 (http://www.megasoftware. net). HA, hemagglutinin; $M$, matrix; NA, neuraminidase; NS1, nonstructural protein 1; NP, nucleoprotein; PA, polymerase acidic; PB, polymerase basic. Scale bars indicate nucleotide substitutions per site. low rate of nonsynonymous substitutions in the HLencoding genes of bat influenza A virus variants was reminiscent of strong purifying selection acting on the hemagglutinin genes in avian-specific influenza A virus strains (11). This finding may suggest comparable evolutionary dynamics between chiropteran and avian reservoirs. Definite assessments will require considerably larger datasets of bat influenza A virus strains.

A. lituratus bats and $A$. planirostris bats, in which HL18NL11 was originally detected in Peru, represent closely related, yet genetically and morphologically clearly distinct bat species (12). The distribution of these bat species overlaps (Figure 1, panel A), potentially facilitating virus exchange across the populations. Phylogenetic analyses confirmed the close genetic relationship between Peru and Brazil HL18NL11 variants across all 8 segments (Figure 2; Appendix Table 2), suggesting lack of reassortment events according to the available data. Our data thus suggest host associations of HL18NL11 beyond the species level, comparable to genus-level host associations of other batborne RNA viruses such as coronaviruses (13).

\section{Conclusions}

The zoonotic potential of HL18NL11 is unclear, yet humanderived cell lines were susceptible to infection by chimeric vesicular stomatitis virus pseudotyped with HL18 (14). The abundance of A. lituratus bats within Latin America (Figure 1, panel A) may thus facilitate spillover infections into other vertebrates across an underrecognized geographic and host range. Finally, Artibeus spp. bats have been used previously for infection studies including viruses with evolutionary origins in bats, such as Middle East respiratory syndrome coronavirus (15). The relatively large body size of A. lituratus bats $(\approx 65 \mathrm{~g})$ and ease of keeping these bats under laboratory conditions may thus facilitate experimental infection studies for HL18NL11 to elucidate the exact sites of HL18NL11 replication, receptor usage, and mode of transmission.

\section{Acknowledgments}

We thank Mariana Cristine Pereira de Souza, Cairo Monteiro de Oliveira, and Luciano Matsumiya Thomazelli for laboratory support. 
This work was supported by FAPESP (São Paulo Research Foundation) through grants 2017/20744-5, 2014/15090-8, 2014/16320-7, 2013/11006-0, and 2008/57687-0 and the European Union's Horizon 2020 research and innovation programme through the ZIKAlliance project (grant agreement no. 734548 ) to J.F.D.

\section{About the Author}

Dr. Campos is a postdoctorate researcher affiliated with the University of Sao Paulo and Charité-Universitätsmedizin Berlin. Her research focuses on emerging viruses from bats.

\section{References}

1. Olsen B, Munster VJ, Wallensten A, Waldenström J, Osterhaus ADME, Fouchier RAM. Global patterns of influenza a virus in wild birds. Science. 2006;312:384-8. http://dx.doi.org/10.1126/ science. 1122438

2. Brunotte L, Beer M, Horie M, Schwemmle M. Chiropteran influenza viruses: flu from bats or a relic from the past? Curr Opin Virol. 2016;16:114-9. http://dx.doi.org/10.1016/j.coviro.2016.02.003

3. Olival KJ, Hosseini PR, Zambrana-Torrelio C, Ross N, Bogich TL, Daszak P. Host and viral traits predict zoonotic spillover from mammals. Nature. 2017;546:646-50. http://dx.doi.org/10.1038/ nature22975

4. Tong S, Li Y, Rivailler P, Conrardy C, Castillo DA, Chen LM, et al. A distinct lineage of influenza A virus from bats. Proc Natl Acad Sci U S A. 2012;109:4269-74. http://dx.doi.org/10.1073/ pnas. 1116200109

5. Tong S, Zhu X, Li Y, Shi M, Zhang J, Bourgeois M, et al. New World bats harbor diverse influenza A viruses. PLoS Pathog. 2013;9:e1003657. http://dx.doi.org/10.1371/journal.ppat.1003657

6. García-Sastre A. The neuraminidase of bat influenza viruses is not a neuraminidase. Proc Natl Acad Sci U S A. 2012;109:18635-6. http://dx.doi.org/10.1073/pnas.1215857109

7. Goes LGB, Campos ACA, Carvalho C, et al. Genetic diversity of bats coronaviruses in the Atlantic Forest hotspot biome, Brazil. Infect Genet Evol. 2016;44:510-3.
8. Anthony SJ, Islam A, Johnson C, Navarrete-Macias I, Liang E, Jain K, et al. Non-random patterns in viral diversity. Nat Commun. 2015;6:8147. http://dx.doi.org/10.1038/ncomms9147

9. Drexler JF, Corman VM, Wegner T, Tateno AF, Zerbinati RM, Gloza-Rausch F, et al. Amplification of emerging viruses in a bat colony. Emerg Infect Dis. 2011;17:449-56. http://dx.doi.org/ 10.3201/eid1703.100526

10. Zhu X, Yu W, McBride R, Li Y, Chen LM, Donis RO, et al. Hemagglutinin homologue from H17N10 bat influenza virus exhibits divergent receptor-binding and $\mathrm{pH}$-dependent fusion activities. Proc Natl Acad Sci U S A. 2013;110:1458-63. http://dx.doi.org/10.1073/pnas.1218509110

11. Rejmanek D, Hosseini PR, Mazet JAK, Daszak P, Goldstein T. Evolutionary dynamics and global diversity of influenza A virus. J Virol. 2015;89:10993-1001. http://dx.doi.org/10.1128/ JVI.01573-15

12. Larsen PA, Marchán-Rivadeneira MR, Baker RW. Speciation dynamics of the fruit-eating bats (genus Artibeus): with evidence of ecological divergence in Central American populations. In: Adams RA, Pedersen SC, editors. Bat evolution, ecology, and conservation. New York: Springer Science + Business Media; 2013. p. 315-339. https://doi.org/10.1007/ 978-1-4614-7397-8

13. Drexler JF, Corman VM, Drosten C. Ecology, evolution, and classification of bat coronaviruses in the aftermath of SARS. Antiviral Res. 2014;101:45-56. http://dx.doi.org/10.1016/ j.antiviral.2013.10.013

14. Moreira ÉA, Locher S, Kolesnikova L, Bolte H, Aydillo T, García-Sastre A, et al. Synthetically derived bat influenza A-like viruses reveal a cell type- but not species-specific tropism. Proc Natl Acad Sci U S A. 2016;113:12797-802. http://dx.doi.org/ 10.1073 pnas. 1608821113

15. Munster VJ, Adney DR, van Doremalen N, Brown VR, Miazgowicz KL, Milne-Price S, et al. Replication and shedding of MERS-CoV in Jamaican fruit bats (Artibeus jamaicensis). Sci Rep. 2016;6:21878. http://dx.doi.org/10.1038/srep21878

Address for correspondence: Jan Felix Drexler, Helmut-Ruska-Haus, Institute of Virology, Campus Charité Mitte, Charitéplatz 1, 10098 Berlin, Germany; email: felix.drexler@charite.de

\section{EID Podcast: Bat Flight and Zoonotic Viruses}

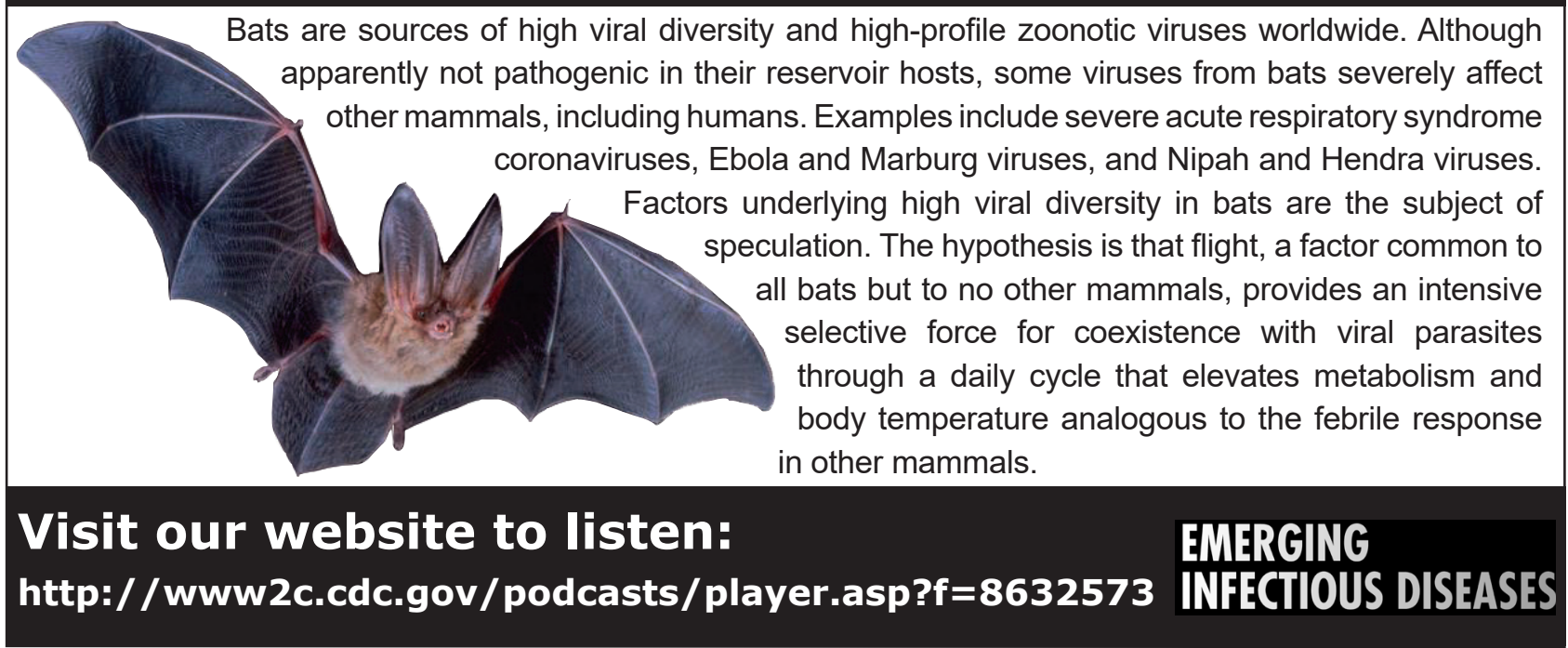

